\title{
Recognition Of Foreign Divorces
}

The number of divorces has increased many fold since the time of Henry VIII. No doubt Henry would be envious of the facility with which a divorce can be obtained now, but "the other side of the fence" in the United States is only a light green. All forty eight states permit divorce, and the grounds vary from adultery only to mental cruelty; the residence requirements vary from six weeks to two years. Today, with our great transient population, this situation gives rise to many conflict of law problems. Also, it is only natural for persons, who are financially able, to go from one State to another to take advantage of less stringent divorce laws. The problem is: What recognition must a State give these migratory divorces?

\section{General Considerations And Historical Bagkground}

The answer to this problem at the present time apppears to lie in the construction given the full faith and credit clause of the federal constitution $^{1}$ by the United State Supreme Court. In the early case of Mills $v$. Duryea, ${ }^{2}$ the court declared a foreign judgment record duly authenticated as provided by the Act of 1790 was conclusive evidence in an action on the foreign judgment in a sister State and was not subject to collateral attack. ${ }^{3}$ Sixty years later the court in Thompson $v$. Whitman ${ }^{4}$ qualified the board language of Mills v. Duryea, supra, and stated that "the jurisdiction of the court by which a judgment is rendered in any State may be questioned in a collateral proceeding in another State notwithstanding the fourth article of the Constitution and the law of 1790, and notwithstanding the averments contained in

1 U. S. Const. ART. IV, $\$ 1$ "Full Faith and Credit shall be given in each State to the public Acts, Records and judicial Proceedings of every other State. And the Congress may by general Laws prescribe the Manner in which such Acts, Records and Proceedings shall be proved, and the effect thereof."

The Act of May 26, 1790, I STAT. 122 (1790), as amended, 28 U.S.C. $\$ \$ 1738,1739$ (Supp. 1950), provided that "Such . . judicial proceedings, or copies thereof, . . . shall have the same full faith and credit in every court within the United States and its Territories and Possessions as they have by law or usage in the courts of such State, Territory or Possession from which they are taken."

27 Cranch 481 (U.S. 1813).

3 The difference between a direct attack and a collateral attack upon a judgment is that the former is an attempt to have a judgment or decree declared void in a proceeding instituted for that specific purpose whereas the latter is an attempt to impeach the validity or binding effect of the decree as a side issue in a proceeding instituted primarily for some other purpose. FreEMan, LAw OF JUDGMENTs $\$ 306$ (5th ed. 1925).

485 U.S. 457 (1873). 
the record itself."s Today, the Constitutional mandate and the Act of 1790 , as amended, require "the record of every judgment . . . duly authenticated and offered in evidence in another state (be accorded) the same faith and credit to which it was entitled in the state whence it was taken" 6 except when it is proved the foreign court had no jurisdiction of the person or of the subject matter. ${ }^{7}$

In the recognition of foreign divorces, this means the forum cannot redetermine the substantive grounds of a foreign divorce no matter how erroneous they are, but only may re-examine the jurisdictional facts supporting the decree. This leaves one question: What are the jurisdictional fact(s) of divorce? In the historic Williams cases ${ }^{8}$ the Supreme Court held that the jurisdictional basis for a foreign ex parte divorce is domicile, and where there is a bona fide domicile the divorce must be given full faith and credit; but, if there is no bona fide domicile the decree is void and need not be recognized.9 However, full faith and credit does not stop a State from recognizing a foreign divorce under the principles of comity if procedural due process is satisfied in the State which rendered the decree. ${ }^{10}$

With this in mind, I would like to examine some of the situations that have arisen and may arise in the future in relation to this probIem.

5 Ibid at 469 . "It is only when the jurisdiction of the court in another state is not impeached, either as to subject matter or the person, that the record of the judgment is entitled to full faith and credit." 1 KENT's Commentaries 281. The jurisdiction of 2 foreign court may be assailed by parol evidence which is in absolute contradiction to recitals of jurisdiction in the record. FrEEMAN, LAW OF JUDGMENTS 1366 (5th ed. 1925).

6 FreEMan, LAW of JUDGMENTs \& 1366 (5th ed. 1925).

$\checkmark$ Thompson v. Whitman, 85 U.S. 457 (1873).

8 Williams v. North Carolina, 317 U.S. 287 (1942); Williams v. North Carolina, 325 U.S. 226 (1945). Also see, Bell v. Bell, 181 U.S. 175 (1901).

Prior to the Williams cases a foreign divorce was only accorded full faith and credit when both parties appeared in the action, or when the decree was granted in a State, which at the time it was granted, was the domicile of both spouses, or when the decree was granted at the matrimonial domicile. A foreign ex parte decree granted at the domicile of one of the spouses was not entitled to full faith and credit unless that State was also the matrimonial domicile. Haddock v. Haddock, 201 U.S. 867 (1905).

For an excellent discussion see, Stumberg, Jurisdiction to Divorce, $24 \mathrm{TEx}_{\mathrm{E}} \mathrm{L}$. Rev. 119 (1946).

9 In the Williams cases, the Court said divorce is neither an action in personam or in rem, but did admit that divorce had elements peculiarly in rem in nature. It is commonly declared that divorce is an action to change 2 status, and since this status is so intimately interrelated with the public welfare some real connection is required with the State which grants the divorce in order to protect the public interest. This connection is domicile.

10 Herron v. Passailaigue, 92 Fla. 818, 110 So. 593 (1926); Miller v. Millex, 200 Iowa 1193, 206 N.W. 263 (1925). Since the Williams cases the recognition of foreign divorces under the principles of comity has appreciably lessened. 


\section{Foreign ex parte Divorces}

When Mr. Jones goes to Nevada and procures an ex parte divorce must Ohio recognize it? In the Williams cases, supra, the Supreme Court held these divorces were entitled to full faith and credit if the plaintiff was a bona fide domiciliary of the state which granted the divorce.11

Fear has been expressed that if domicile is the controlling factor there is nothing to stop Nevada and a few other States which grant "across the counter" divorces from reducing this period to a month or a week or even a day. At the present time there is no case in point on these facts, but the court in the first Williams case ${ }^{12}$ went to great pains to express that their decision did not impose Nevada law upon North Carolina nor did it impose North Carolina law upon Nevada, and from this it would seem, in balancing the conflicting interests of two states, the Court would set a minimum residence period and call any shorter period a denial of procedural due process to the absent spouse. ${ }^{13}$ In support of this conclusion, is the fact that in several recent decisions the Supreme Court, in upholding foreign contested divorces, has pointed out that procedural due process was not violated.14

\section{Foreign Contested Divorces}

The degree of recognition that must be given a foreign divorce when the defendant personally appears in the proceeding has been determined in three recent Supreme Court decisions. ${ }^{15}$ The Court ex-

11 Williams v. North Carolina, 325 U.S. 226 (1945). This is a question of fact to be determined according to reasonable rules of evidence promulgated by the laws of the forum.

12317 U.S. 287, 303 (1942).

13 Pennoyer v. Neff, 95 U.S. 714 (1877).

14 Sherrer v. Sherrer, 334 U.S. 348 (1948); Coe v. Coe, 334 U.S. 384 (1948); Estin v. Estin, 394 U.S. 541 (1948).

18 Davis v. Davis, 305 U.S. 32 (1938). Mrs. Davis, in an action in the District of Columbia, challenged the validity of 2 prior Virginia divorce decree. Mrs. Davis had appeared in the Virginia action and contested the jurisdictional issue which was decided against her. The lower court found that the Virginia court had no jurisdiction but was reversed by the Supreme Court which said the determination of this issue by the Virginia court was res adjudicata.

Sherrer v. Sherrer, 334 U.S. 343 (1948). Mrs. Sherrer instituted a divorce action in Florida. Mr. Sherrer retained Florida counsel, and, in his answer, denied Mrs. Sherrer's allegation of a bona fide Florida residence; however, a settlement was agreed upon, and at the hearing the issue of domicile was not raised. In a later proceeding in Massachusetts, the Supreme Court declared the jurisdictional issue in the Florida action was res adjudicat2 since the parties had full opportunity to litigate it.

Coe v. Coe, 334 U.S. 378 (1948). This case is similar to Sherrer v. Sherrer, supra, except the defendant's answer admitted the bona fides of the plaintiff's Nevada 
pressed itself thus: "... the requirements of full faith and credit bar a defendant from collaterally attacking a divorce decree on jurisdictional grounds in the courts of a sister State where there has been participation by the defendant in the divorce proceedings, where the defendant has been accorded full opportunity to contest the jurisdictional issues (regardless if he avails himself of the opportunity or not), and where the decree is not susceptible to such collateral attack in the courts of the state which rendered the decree."16

\section{Recognition Of Foreign Divorces in Criminal Actions}

The Williams cases, supra, declared what recognition North Carolina had to give a Nevada divorce in a bigamy prosecution. ${ }^{17}$ As previously stated, this is determined by the bona fides of the accused's domicile in the divorce state.

One question remains open here. Would the results of the Williams cases be changed if the foreign divorce was contested instead of ex parte? Under the elementary principles of res adjudicata a person is not estopped from collaterally attacking a judgment to which he was neither a party nor a privy. There is no reason why the immediate point at hand is not covered by the general rule, ${ }^{18}$ as a state is not a party to a foreign divorce action either contested or ex parte.

\section{DIVISIBLE DIVORce}

In Estin v. Estin, 19 the Supreme Court recognized the divisible divorce. The underlying premise of this concept is that the institution of marriage is not a unitary status but is a complex of legal relations some of which may be terminated by ex parte divorces and

domicile. The Nevada decree was held to be res adjudicata in a subsequent Massachusetts proceeding as defendant had full opportunity to litigate the jurisdictional issue.

16 Sherrer v. Sherrer, 334 U.S. 343, 351 (1948).

17 Mr. Williams and Mrs. Hendrix left their respective spouses in North Carolina and went to Nevada where they procured ex parte divorces. They were married in Nevada and returned to North Carolina where they were indicted and convicted of bigamy.

18 REstatement, JUDGMENTs $\$ 79$ and $\$ 83$.

$\S 79$. "A person who at the time of rendition of a valid judgment is a party to the action is bound by and entitled to the benefits of the rules of res adjudicata..."

\$ 83. "A person who is not a party but who is in privity with the parties in an action terminating in a valid judgment is . . . bound by and entitled to the benefits of the rules of res adjurdicata."

19334 U.S. 54 I (1948). 
some of which may not.20

In 1943, Mrs. Estin was awarded a support and maintenance decree in a New York proceeding in which Mr. Estin personally appeared. Two years later he procured a Nevada ex parte divorce and soon thereafter ceased making payments under the support and maintenance decree. In an action for arrearages, the lower New York courts, affirmed by the Court of Appeals, held for Mrs. Estin, although they admitted Mr. Estin had acquired a bona fide Nevada domicile. ${ }^{21}$ The Supreme Court, through Mr. Justice Douglas, said: The result in this decision is to make the divorce divisible-to give effect to the Nevada decree in so far as it affects marital status and to make it ineffective on the issue of alimony.22

The Court proceeded on two distinct grounds. The first was that the judgment as handed down accommodated the "legitimate interests" of both New York and Nevada in that "New York was rightly concerned lest the abandoned spouse be impoverished and become a public charge," and that Nevada was primarily concerned with the marital status of its domiciliaries with regard to their capacity to remarry. The second ground was that the New York decree for alimony alone was an intangible property right, and under cardinal principles of due process could not be taken from Mrs. Estin unless the court had in personam jurisdiction over her. ${ }^{23}$

Mr. Jusctice Jackson and Mr. Justice Frankfurter dissented on the ground that the New York decision denied full faith and credit to the Nevada divorce. Mr. Justice Jackson said: "As I understand New York law, if, after a decree for separation and alimony, the husband had obtained a New York divorce against his wife, it would terminate her right to alimony. If the Nevada judgment is to have full faith and credit, I think it must have the same effect a similar New York decree would have."24 The majority of the Court summarily disposed of this point by saying that the highest court of New York had held in this case that under New York law a support order survived subsequent divorce, and this conclusion was binding on the Court "except as it conflicts with the Full Faith and Credit clause."25

Actually, the approach of the dissenters appears to be a reverse application of the full faith and credit clause, for, in the ordinary situation, a court is required to give the judgments of sister States the same faith and credit they receive in the jurisdiction in which they

20 Bingham, The American Law Institute vs. The Supreme Court In the Matter of Haddock v. Haddock, 21 CoRNeLl L.Q. 393, 416 (1936). Cook, Is Haddock v. Haddock Overruled, 18 IND. L.J. 165, 172 (1943).

21 Estin v. Estin, 296, N.Y. 308, 73 N.E. 2d 113 (1947).

22334 U.S. 541, 549 (1948).

23 Pennoyer v. Neff, 95 U.S. 714 (1877).

24334 U.S. 541, 544 (1948).

25334 U.S. 541 (1948). 
were rendered. But, here, it is being asked that a foreign judgment be given the same faith and credit as a similar domestic judgment would receive in the forum. It has been suggested that the dissenters did not mean the full faith and credit clause but actually had in mind either the equal protection or the privileges and immunities clause. ${ }^{26}$ However, by way of conjecture, it seems the justices would not make a basic error, but actually had in mind an increase in the scope of the full faith and credit clause.

Assuming New York law, like that of Pennsylvania, affirmatively declared that divorce terminated prior support decrees, could New York discriminate against foreign ex parte divorces by saying the law terminating prior judgments for support was only applicable to domestic divorces? Would New York be allowed to give greater faith and credit to domestic divorces than to foreign divorces? The dissenters in the Estin case supra, felt this was the situation the court was faced with and found a denial of full faith and credit. Conceivably, the majority opinion could be squared with this view by saying the majority felt the New York cases on this point were inconclusive, and the decision of the Court of Appeals was not discriminatory towards the Nevada decree but was merely a determination of the existing New York law. This thought is fortified by Mr. Justice Douglas' statement in the majority opinion to the effect that the opinion of the Court of Appeals was binding on the Supreme Court "except as it conflicts with the Full Faith and Credit Clause.27 This statement, taken together with the dissenting opinion, appears to leave an opening for the Court to adopt the reverse application of full faith and credit. If this should be the case there is no doubt that New York would be prohibited from denying a federal right by giving greater faith and credit to domestic judgments than to valid foreign judgments. If New York is, in effect, discriminating in this manner a case should be forthcoming soon.

It should be mentioned that support and maintenance is not the only aspect of divisible divorce. Other interests which could well be handled in the same manner are legitimacy of children, property in-

26 "In the Estin $v$. Estin situation, the full faith and credit clause and the act of Congress made thereunder would appear to require New York to give Nevada divorce decrees 'the same faith and credit ... as they have by law or usage in the courts of such state from which they are taken; i.e. the same faith and credit as they have in Nevada. The full faith and credit clause and the act of Congress would not appear to require New York to give Nevada divorces the same effect as New York divorces. Accordingly, although Mr. Justice Frankfurter and Mr. Justice Jackson specifically refer to the full faith and credit clause it has been conjectured that it was the privileges and immunities clause or the equal protection clause which they really had in mind." J.H.C. Morris, Divisible Divorce, 64 HARv. L. REv. 1287, 1299 (1951).

27 Estin v. Estin, 334 U.S. 541, 544 (1948). (Emphasis added). 
terests of the spouses and amenability to criminal prosecution.

\section{ALIMONY 28}

There are two broad problems in this area: (1) What recognition must be given foreign alimony decrees and judgments in which both spouses participated; and, (2) does the procurement of a foreign ex parte or contested divorce estop either spouse in a subsequent action for alimony alone?

\section{(1) Recognition of Foreign Decrees.}

The decree of recognition a State must accord a foreign alimony decree is also determined by the interpretation given the full faith and credit clause. As a general rule, the test is whether the foreign decree is final or is subject to modification and recall in the State in which it was gxanted. If it is final it falls within the protection of the full faith and credit clause; if it is not final it does not receive this protection for to do so would give the decree greater faith and credit than it is entitled to in the State in which it was rendered.

Generally, there are two types of alimony judgments; those calling for a lump sum payment, and those calling for installment payments. At an early date the Supreme Court declared that accrued installments not subject to modification were entitled to full faith and credit even though they had not been reduced to judgment in the state which granted the alimony decree.29

As has already been stated, a decree for installments subject to retroactive modification after the accrual of the installments is denied recognition in the vast majority of States on the basis that it lacks the requisite finality. ${ }^{30}$ Ohio adheres to the majority view. ${ }^{31}$ In one case, however, it was declared that full faith and credit demands that alimony decrees subject to retroactive modification be recognized as to accrued installments until they are modified. ${ }^{32}$ It is interesting to note the Supreme Court has held that a court may, without violating

28 Alimony is an action in personam, and before any award may be granted the spouse sought to be charged therewith must be personally before the court.

20 Barber v. Barber, 21 How. 582 (U.S. 1858).

30 Scudder v. Scudder, 11 Alaska 303 (1949); Cohen v. Cohen, 158 Fla. 307, 30 So. $2 d 307$ (1948); Webster v. Webster, 177 La. 306, 148 So. 241 (1933); Wilson v. Wilson, 143 Me. 113, 56 A. 2d 453 (1948); Skinner v. Skinner, 205 Mich. 243, 171 N.W. 383 (1919); Johnson v. Johnson, 196 Misc. 487, 92 N.Y.S. 2d 517 (Sup. Ct. 1950); Hewett v. Hewett, 44 R.I., 308, 116 A. 883 (1922) ; Rumpf v. Rumpf, 237 S.W. 669 (Tex. Civ. App. 1951).

31 Armstrong v. Armstrong, 117 Ohio St. 558, 160 N.E. 34 (1927) ; Gilbert v. Gilbert, 83 Ohio St. 265, 94 N.E. 421 (1911).

82 Holton v. Holton, 153 Minn. 346, 190 N.W. 542 (1922). 
full faith and credit, modify a foreign divorce decree which is subject to modification in the state in which it was granted. ${ }^{33}$ Some States hold that although this situation is not within the coverage of the full faith and credit clause recognition will be given on the principles of comity. ${ }^{34}$ California and a few other Western States have extended comity recognition to include the enforcement of prospective payments under foreign decrees. ${ }^{35}$

In spite of the great number of State opinions to the contrary, there is a valid argument that full faith and credit must be given to accrued alimony subject to retroactive modification. This exact point has never been determined by the Supreme Court, and all the State opinions are based on the interpretation of the early case of Sistare $v$. Sistare. ${ }^{36}$ In Barber v. Barber, ${ }^{37}$ the court took the broad position that a decree for alimony was entitled to full faith and credit "until the decree has been recalled, as any other judgment for money is." 38 Forty years later the court retracted some what in Lynde v. Lynde, ${ }^{39}$ a most brief opinion which made no mention of the Barber case. Mrs. Lynde, in a New Jersey proceeding, was awarded a lump sum of $\$ 8,840$ and $\$ 80$ a week for future alimony. She brought suit on this decree in New York where judgment was awarded for the fixed sum but not for the accrued installments. The Supreme Court, in affirming the New York decision, said: "The decree for the payment of the $\$ 8,840$ was a fixed sum already due, and the judgment of the court below was properly restricted to that. The provision of the payment for alimony in the future was subject to the discretion of the Court of Chancery of New Jersey, which might at any time alter it and was not a final judgment for a fixed sum." 40 Nine years later in Sistare v. Sistare, supra, it was contended that the Barber case had been partially overruled by the Lynde case. The Court attempted to reconcile the two cases but stated that in any event the Lynde case should be qualified so as not to overrule the Barber case. The Court then laid down two broad propositions that were to declare the law: "First - that generally speaking, where a decree is rendered for alimony and is made payable in future installments the right to such installments becomes

33 Holvey v. Holvey, 390 U.S. 610 (1947).

34 Biewend v. Biewend, 17 Cal. 2d 108, 109 P. 2d 701 (1941); Espeland v. Espeland, 111 Mont. 365, 109 P. 2d 792 (1941); Cousineau v. Cousineau, 155 Ore. 184, 63 P. 2d 897 (1936); Shibley v. Shibley, 181 Wash. 166, 44 P. 2d 446 (1935).

35 Biewend v. Biewend, 17 Cal. 2d 108, 109 P. 2d 701 (1941); Cousineau v. Cousineau, 155 Ore. 184, 63 P. 2d 897 (1936); Shibley v. Shibley, 181 Wash. 166, 44 P. $2 \mathrm{~d} 446$ (1935).

36218 U.S. 1 (1909).

3721 How. 582 (U.S. 1858).

38 Id. at 595.

38181 U.S. 183 (1900).

$40 \mathrm{Id}$. at 187. 
absolute and vested on becoming due, and is there protected by the full faith and credit clause, provided no modification of the decree has been made prior to the maturity of the installments, ... . . Second, that this general rule, however, does not obtain where by the law of the State in which a judgment for future alimony is rendered the right to demand and receive such future alimony is discretionary with the court which rendered the decree to such an extent that no absolute or vested right attached to receive the installments ordered by the decree to be paid, even though no application to annul or modify the decree in respect to alimony had been made prior to the installments becoming due." 41 From this language the State courts conceived the finality test. In 1944, another Barber ${ }^{22}$ case reached the Supreme Court. The Court did not find it necessary to discuss the problem of what faith and credit must be given accrued installments subject to retroactive modification but added oil to the flame by saying: " . . . it is unnecessary to consider whether a decree or judgment for alimony already accrued, which is subject to modification or recall in the forum which granted it, but is not yet so modified, is entitled to full faith and credit until such time as it is modified." 43

From a social viewpoint it is most desirable to demand that this type of decree be given full faith and credit. Under the "finality" rule a husband can evade his moral and legal duty of supporting his exspouse by merely moving to another State. The wife, who in the majority of cases is the destitute party, must either follow her husband or get the accrued installments reduced to judgment, and before she can do the latter, notice must be given the husband in order to satisfy procedural due process. ${ }^{44}$ The unfairness of this is apparent.

From the legal viewpoint it must be noted the Supreme Court has never unequivocally adopted the finality test but said in the Sistare case full faith and credit did not attach when the right to receive such accrued installments was discretionary "to such an extent" with the court which granted the decree that no "absolute or vested right" existed to receive the installments. Further, it should be kept in mind that the Court in the Sistare case said that Lynde v. Lynde, supra, was

41218 U.S. I, 16 (1909).

42323 U.S. 77 (1949).

43 Id. at 81 .

44 Griffin v. Griffin, 327 U.S. 220 (1946), reh. denied, 328 U.S. 876 (1946). The Court in the Griffin case did not say exactly what type of notice would suffice. The Court said in reference to the action reducing the alimony arrearages to judgment: “... we find ... that due process ... does require further notice of the time and place of such further proceedings ...." At another place the Court said the judgment could not be granted against the absent husband " . . . without some form of notice by personal or substituted service." The dissenting judges, Mr. Justice Rutledge, Mr. Justice Frankfurter, and Mr. Justice Black, felt there was no denial of due process because the Court in rendering the initial alimony decree procured jurisdiction to later reduce any arrearages to judgment. 
not to overrule the earlier Barber case, and in the second Barber case the court definitely threw out an invitation for this point to be litigated and thus showed the issue was far from settled in the minds of the Justices. The final answer appears to depend on whether the Court will or will not characterize accrued installments subject to modification "absolute and vested." As a practical matter it seems to deny full faith and credit to refuse to recognize accrued installments subject to modification almost as much as it would to refuse to recognize decrees not subject to modification, because unless extenuating circumstances exist courts are most hesitant to modify an alimony judgment. It is suggested that the right to this type of alimony is "absolute and vested".

When accrued installments subject to modification are reducea to final judgment, full and complete recognition must be given the judgment. ${ }^{45}$ Furthermore, clear and convincing proof is required before a court may find such a judgment is subject to modification. ${ }^{46}$

The majority of courts refuse to recognize decrees for prospective payments, not yet accrued.47 Under the finality test this is sound because these are almost universally subject to modification in the forum in which they are rendered. However, as has been pointed out, a few states allow recognition and enforce them in the same manner as domestic decrees are enforced. 48

Alimony pendite lite is also refused recognition because in practically all cases it is subject to the discretion of the court which granted it. 49

Once a foreign judgment for alimony is recognized the majority of States receive it as evidence in support of a domestic judgment which is enforced and executed as any other judgment at law. ${ }^{50} \mathrm{~A}$ few jurisdictions follow what seems to be a more enlightened approach and enforce foreign alimony decrees exactly the same as domestic alimony decrees, ${ }^{51}$ i.e., equitable remedies are available to the plaintiff.

\section{(2) Foreign Decrees and Res Adjudicata}

Will parties to a foreign divorce be estopped from later prosecuting

45 Barber v. Barber, 323 U.S. 77 (1949).

40 Ibid.

47 See note 3, supra.

48 See note 7, supra.

49 Geisler v. Geisler, 124 Ky. 292, 98 S.W. 1023 (1907) ; Kelly v. Kelly, 121 N.J. Eq. 361, 189 A. 665 (1937); Henry v. Henry, 74 W. Va. 563, 82 S.E. 522 (1914).

50 Jacobs, The Enforcement of Foreign Decrees for Alimony, 6 LAw and ConTEMPORARY Problems 250, 267 (1939), and cases cited.

51 German v. German, 122 Conn. 155, 188 A. 429 (1936); Sackler v. Sackler, - Fla. —- 47 So. 2d 292 (1951); Summers v. District Court, - - Nev. 227 P. 2d 201 (1951). cf Thones v. Thones, 125 Tenn. 184, 203 S.W. $2 d 597$ (1948). Also see note 7 , supra. 
an action for alimony alone? Where both spouses appear in the foreign action this is practically a moot question since alimony provisions are usually handed down along with the divorce decree. If the foreign divorce is ex parte a different problem exists.

When both spouses appear in the foreign action, the general rules of res adjudicata would seem to preclude a subsequent determination of alimony in a sister State. ${ }^{52}$ There is no Supreme Court case in point, and Estin v. Estin, supra, is the case most analagous. Conceivably it could be argued that divorce and alimony are two entirely distinct causes of action, and the failure to ask for alimony in a divorce proceeding would not bar a subsequent action for it. In the Sheerer ${ }^{53}$ and $\mathrm{Coe}^{54}$ cases, the Court declared that if the jurisdictional issue had been litigated, or if a reasonable opportunity to litigate it had been presented, the parties would be estopped from collaterally re-examining the issue in another action. Will the Court apply this reasoning to the issue of alimony? Most courts, under these facts, find an estoppel. ${ }^{55}$ However, in Ohio, a further distinction appears to have been drawn. In Gilbert $v$. Gilbert, ${ }^{56}$ the following facts were present: Mrs. Gilbert obtained a judgment for alimony alone in Ohio; later Mr. Gilbert initiated a divorce action in South Dakota in which Mrs. Gilbert entered an appearance and received alimony which she had asked for; she returned to Ohio and sued for arrearages which were due under the prior Ohio alimony judgment. The Ohio Supreme Court disallowed Mrs. Gilbert's claim stating that since she had submitted all her claims and rights to the jurisdiction of the South Dakota court "she is now estopped and will not be heard to again assert in this state any rights she may have had under the original decree . . ."57 In Manney v. Manney, ${ }^{58}$ the Court of Appeals of Montgomery County, distinguished the Gilbert case. The facts were the same as in the Gilbert case except Mrs. Manney in answering her husband's Nevada divorce petition did not ask for alimony. Mr. Manney stopped making payments under a previous Ohio judgment for alimony alone, and the court of appeals ordered him to pay, stating that Mrs. Manney was not estopped as she appeared in the Nevada action only to refute the ac-

52 RfSTATEMENT, JUDGMENTs. p. 159 (Introductory material to res adjudicata). "Where, therefore, the second action is based upon the same cause of action as that upon which the first action was based, the judgment is conclusive as to all matters which were litigated or might have been litigated in the first action."

53334 U.S. 343 (1948).

54334 U.S. 378 (1948).

55 Norris v. Norris, 200 Minn. 246, 273 N.W. 708 (1937); Lynn v. Lynn, 302 N.Y. 193, 97 N.E. 2d 748 (1951); Schacht v. Schacht, 295 N.Y. 439, 68 N.E. 2d 433 (1946).

5683 Ohio St. 265, 94 N.E. 421 (1911).

57 Id. at 271 .

$58-$ Ohio App. -59 N.E. 2d 755 (1944). Accord. Metzger v. Metzger, 32 Ohio App. 202, 167 N.E. 690 (1929). 
cusations her husband had made in his petition and not to litigate the issue of alimony. Further, it made no difference that Mrs. Manney had reasonable opportunity to litigate the issue of alimony. It should be noted that the court held this way in spite of the fact that Mrs. Manney in the prayer of her answer asked for such other relief as "may be meet and equitable." From an interpretation of these cases, the Ohio law appears to estop a wife's claim for alimony alone, past or future, where she either (1) instituted the foreign divorce action; or, (2) filed a cross petition; or (3) asked for alimony in her answer.

In the majority of states, a wife is not barred from a subsequent action for alimony when her husband obtained a foreign ex parte divorce. ${ }^{59}$ The concept of divisible divorce, as set forth in Estin $v$. Estin, supra, supports this approach to a great extent.

The few cases in point are about evenly divided as to whether a wife who receives a foreign ex parte divorce may later sue for alimony alone. ${ }^{60}$

\section{Divorces Obtained In Foreign Nations}

The full faith and credit clause does not apply to judgments or decrees granted in foreign nations, and any recognition accorded them is based upon the principles of comity. ${ }^{61}$

As a general rule foreign judgments and decrees of divorce are recognized; ${ }^{62}$ however, if the procedure or substantive divorce law of the nation is repugnant to the public policy of the forum recognition is denied. ${ }^{63}$ This general rule obtains regardless of whether the foreign

50 Cox v. Cox, 19 Ohio St. 502 (1869); Slapp v. Slapp, 73 Ohio App. 444, 57 N.E. 2d 81 (1944); Toncray v. Toncray, 123 Tenn. 476, 191 S.W. 977 (1910). Honaker v. Honaker, 218 Ky. 212, 291 S.W. 42 (1927).

60 Accord: Woods v. Waddle, 44 Ohio St. 449, 8 N.E. 297 (1886); Weck $\nabla$. Weck, 58 Ohio App. 72, 15 N.E. 2d 780 (1938); Stephenson v. Stephenson, 54 Ohio App. 239, 6 N.E. 2d 1005 (1937); Hutton v. Dodge, 58 Utah 228, 198 P. 165 (1921). Contra: Doeksen v. Doeksen, 214 Ia. 17, 241 N.W. 487 (1926); McFarlane v. McFarlane, 42 Ore. 477, 73 P. 203, 75 P. 139 (1903); Darby v. Darby, 152 Tenn. 287, 277 S.W. 894 (1926).

61 Hilton v. Guyot, 159 U.S. 113, (1895). The reason for this distinction is that foreign nations are not "other State (s)" within the meaning of the full faith and credit clause.

62 Redeker v. Redeker, — Cal. —-, 221 P. $2 d 1$ (1951); Pawley v. Pawley, — Fla. _-_, 46 So. 2d 464, petition denied, 47 So. 2d 546, cert. denied, 340 U.S. 866 (1950); Caulborn v. Joseph, 195 Ga. 723, 25 S.E. 2d 576 (1943); Kenner v. Kenner, 139 Tenn. 211, 201 S.W. 779 (1918).

63 Bethune v. Bethune, 192 Ark. 811, 94 S.W. 2d 1043 (1936); Tonti v. Chadwick, 1 N.J. 531, 64 A. 2d 436 (1949); Caldwell v. Caldwell, 298 N.Y. 146, 81 N.E. 2d 60 (1948); Machransky v. Machransky, 31 Ohio App. 482, 166 N.E. 423 (1927). 
action is contested or is ex parte. ${ }^{64}$

A specific example of the refusal to recognize foreign divorces is the Mexican "mail order" divorce which can be obtained by both parties executing powers of attorney to Mexican counsel thus obviating the necessity of appearance or residence. Uniformly these "mail order" divorces are not recognized. ${ }^{65}$

If both parties were present in the divorce action, which is recognizable under the principles of comity, an action will lie in an American court to enforce alimony payments ordered in the foreign action. ${ }^{68}$

Foreign rabinnical divorces are given or denied recognition on the principles of comity in the same manner as other divorces obtained outside the United States and its possessions. ${ }^{67}$

A somewhat related problem is recognition of divorces obtained in conformity with tribal customs of American Indians. These divorces are recognized if at the time of the divorce the parties lived on the reservation. ${ }^{68}$ However, if the parties leave the reservation they must satisfy the law of their new home. ${ }^{69}$ Some cases hold that it makes no difference whether the husband is a full-blooded Indian or a half-breed or even a white man. ${ }^{70}$

\section{Collateral Attack of Foreign Divorges by Third Persons}

The very recent case of Johnson v. Muelberger ${ }^{71}$ held that a stranger to a foreign divorce action could not collaterally attack the divorce in another state unless such attack was allowed in the state which granted the divorce. The Court would not permit a daughter in a New York proceeding to collaterally attack on jurisdictional grounds her deceased father's Florida divorce. Since the divorce could

64Pawley v. Pawley, — Fla. —- 46 So. 2d 464, petition denied, 47 So. $2 d$ 546, cert. denied, 340 U.S. 866 (1950) ; Kapigian v. Der Minassian, 212 Mass. 412, 99 N.E. 264 (1912).

65 Christopher v. Christopher, 198 Ga. 361, 31 S.E. 2d 818 (1944); Caldwell r. Caldwell, 298 N.Y. 146, 81 N.E. $2 d 60$ (1948); De Rosay v. De Rosay, 162 Pa. Super. 333, 57 A. 2d 685 (1948).

66 Mitchell v. Mitchell, 194 Misc. 73, 85 N.Y.S. $2 d 627$ (Sup. Ct. 1949).

67 Matter of Rubenstein, 143 Misc. 917, 257 N.Y.S. 637 (Sur. Ct. 1932); Machransky v. Machransky, 31 Ohio App. 482, 166 N.E. 423 (1927).

68 Begay v. Miller, 70 Ariz. 380, 222 P. 2d 624 (1950); La Framboise v. Day, 136 Minn. 239, 161 N.W. 529 (1917); Thomas v. Healey, 152 Okla. 93, 3 P. 2d 1047 (1931).

60 La Framboise v. Day, 136 Minn. 239, 161 N.W. 529 (1917); In re Wa-ginup's, 57 Utah 29, 192 P. 267 (1920).

70 Cyr v. Wallser, 29 Okla. 281, 116 P. 931 (1911).

71 Johnson v. Muelberger, 340 U.S. 581 (1951). 
not be collaterally attacked in Florida it was entitled to full faith and credit in New York.

\section{FRAUD}

The statement is often made that a foreign divorce may be collaterally attacked on the ground of fraud..$^{22}$ For this result to obtain, the fraud must be of a character which goes to the jurisdiction of the court thus rendering the decree void. However, it must be noted that there is no Supreme Court case directly in point with regard to the entire problem of fraud, and any analysis of the various methods of fraud should not overlook the liberality exercised by the Supreme Court in the recognition of foreign divorces.

Generally speaking, there are five methods of fraud practiced in obtaining foreign divorces. They are: (1) collusion of the parties, (2) fraudulent evidence, (3) fraudulently inducing the other spouse to enter an appearance, (4) withholding from the court the fact of the pendency of a similar action in another State, and (5) secreting the whereabouts of the other spouse.

As has been already stated the tendancy of the Supreme Court in recent years has been to favor the recognition of foreign divorces. By way of conjecture it seems that the Supreme Court would dispose of fraud cases as it did cases regarding the right of third persons to collaterally attack foreign divorces, ${ }^{73}$ i.e., an attack would be allowed only if such were allowed in the State which granted the divorce. Although the Supreme Court has never directly ruled on this issue, there are many state decisions involving the various methods of fraud.

Where the parties collude in obtaining a divorce a subsequent collateral attack is allowed unless an estoppel is found. ${ }^{74}$

The cases involving fraudulent evidence readily break down into two categories; fraud which goes to the substantive grounds for divorce, and fraud which goes to the jurisdictional requirements. In both contested and ex parte divorces the majority of decisions do not allow a collateral attack with respect to fraudulent evidence running to the substantive grounds for divorce. ${ }^{75}$ Nevertheless, the courts allow collateral attack against foreign exparte divorce where the fraud runs

72 Schouler Divorce Manual, \$378 (1944).

73 cf. Johnson v. Muelberger, 340 U.S. 581 (1951).

74 Staedler v. Staedler, 6 N.J. 380, 78 A. 2d 896 (1951).

75 Baldwin v. Baldwin, 28 Cal. 2d 406, 170 P. 2d 670 (1946); Patterson v. Patterson, - Cal. App. - 187 P. $2 d 113$ (1948) ; Nicholson v. Nicholson, 113 Ind. 131, 15 N.E. 223 (1888); Hughes v. Hughes, 211 Ky. 799, 278 S.W. 121 (1925); Keena v. Keena, 222 Mo. App. 825, 10 S.W. 2d 344 (1928); Watters v. Watters, 259 App. Div. 61l, 19 N.Y.S. 2d 995 (Sup. Ct., App. Div. 1940). Contra: Corwin v. Commonwealth, 131 Va. 649, 108 S.E. 651 (1921). 
to the jurisdictional requirements. ${ }^{76}$ This position is supported by two older Supreme Court cases 77 and apparently receives the blessing of the all important "domicile" theory of the Williams cases.78 In cases involving contested divorces, however, the argument could well be made that the parties had opportunity to litigate the issue and, under the reasoning of the Sheerer ${ }^{79}$ and $\mathrm{Coe}^{80}$ cases, are estopped from any collateral re-examination.

The few cases in point decidedly hold that the deceived spouse may collaterally attack a divorce in which her spouse fraudulently induced her to make an appearance ${ }^{81}$ or fraudulently induced her not to contest the action. ${ }^{82}$ Moreover, this appears to be analagous to the situation where a person inveigles another into a state to have service made upon him, and it is practically a rule of thumb that no jurisdiction attaches under these circumstances. ${ }^{83}$ With this background, it is doubtful if even the very liberal Supreme Court would require full faith and credit.

The majority of states find a fraud which goes to the jurisdiction when the spouse who obtains a foreign ex parte divorce conceals the pendency of a similar action by the other spouse in another State. ${ }^{84}$ In regard to pending actions for separate maintenance, there is little doubt but that the Supreme Court would expand Estin v. Estin ${ }^{85}$ to include pending as well as cases already determined.

The courts also generally declare that the concealment of the other spouses whereabouts from the court which granted the divorce is a fraud which goes to the jurisdiction. ${ }^{86}$ This method of fraud ap-

76 Wilkes v. Wilkes, 254 Ala. 54, 16 So. 2d 15 (1944); Azur v. Thomas, 206 Ga. 588, 57 S.E. 2 d 821 (1950); Chapman v. Chapman, 224 Mass. 427,113 N.E. 359 (1916); Wright v. Wright, 350 Mo. 325, 165 S.W. $2 d 870$ (1942). In both the Wilkes and Wright cases the court characterized as direct that which might be called a collateral attack.

77 Bell v. Bell, 181 U.S. 175 (1900); Streitwolf v. Streitwolf, 181 U.S. 179 (1900).

78317 U.S. 287 (1945).

79334 U.S. 343 (1948).

80334 U.S. 378 (1948).

81 Averbuck v. Averbuck, 270 App. Div. 160, 58 N.Y.S. 2d 392 (1st Dep't 1945). Gagliano v. Gagliano, 56 N.Y.S. 619, affm'd, 269 App. Div. 1025, 59 N.Y.S. 2d 377 (Ist Dep't 1945).

82 Daniels v. Benedict, 50 Fed. 347 (1892).

83 Commercial Mut. Acci. Co. v. Davis, 213 U.S. 245 (1909); Urschel v. Hannin, 25 Ohio App. 368, 158 N.E. 550 (1927) .

84 Atkins v. Atkins, 386 Ill. 345, 54 N.E. 2d 488 (1944); Anglin v. City of Omaha, 140 Neb. 147, 294 N.W. 353 (1941); Contra, Rodda v. Rodda, 185 Ore. 140, 220 P. $2 d 616$ (1949). In the Rodda case, a pending action was not involved; a prior order for separate maintenance was in issue.

s5 334 U.S. 541 (1948).

86 In re Nolan's Estate, 56 Ariz. 361, 108 P. 2d 388 (1940); Leichty v. Kansas City Bridge Co., 354 Mo. 629, 190 S.W. 2d 201, cert. den., 327 U.S. 782 (1946); Todd v. Policemen's and Firemen's Pension Fund of Newark, - N.J., —, 82 A. 2d 
pears to be the weakest and one which the Supreme Court might say does not go to the jurisdiction of the court, thereby requiring full faith and credit be given the divorce.

\section{ESTOPPEL}

The scope of this comment does not cover the rule of estoppel as applicable to foreign divorces, but the problem should be recognized and a few examples given.

The premise of estoppel in this area is that a person will be barred from attacking a divorce, which is not under the protection of the full faith and credit clause, because of the existence of certain facts. It should be noted that Estin v. Estin, supra, Sheerer v. Sheerer, supra, and Coe v. Coe, supra, have laid down a definite rule for many questions which previously were determined under the rule of estoppel.

Some of the facts which the courts often find giving rise to an estoppel are: (1) where the spouse who obtained a foreign divorce later wishes to question it; ${ }^{87}$ (2) one who aided his wife in procurring a divorce from her former husband subsequently asserts its invalidity; ${ }^{88}$ (3) a spouse who remarries in reliance on a divorce obtained by her spouse subsequently attacks the divorce; ${ }^{89}$ and (4) where the party attempting the attack is guilty of laches. ${ }^{90}$

In conclusion, the true answer as to when or whether certain facts will constitute an estoppel appears to lie within the courts' discretion and sense of fairness under the circumstances.

\section{Conceusion}

It would be difficult, if not impossible, to draw a hard and fast conclusion applicable to the varied situations arising in relation to the recognition of foreign divorces. Again, it should be pointed out that the Supreme Court apparently still maintains its liberal attitude.

233 (1951). Contra, Commonwealth ex rel. Cronhardt v. Cronhardt, 135 Pa. Super. 117, 4 A. 2d 589 (1939). In both the Leichty and Todd cases, a denial of due process was found under these facts.

87 Krause v. Krause, 282 N.Y. 355, 26 N.E. 2d 290 (1940); McIntyre v. McIntyre, 216 N.C. 698, 191 S.E. 507 (1937) ; Horowitz v. Horowitz, 58 R.I. 396,192 A. 796 (1937).

88 Kaufman v. Kaufman, 177 App. Div. 162, 160 N.Y.S. 19 (App. Div. 3 Dep't (1917).

89 Kelsey v. Kelsey, 203 Cal. 61, 263 P. 200 (1928); Parmlee v. Hutchins, 238 Mass. 561, 131 N.E. 443 (1921).

90 Sleeper v. Sleeper, 129 N.J. Eq. 99, 18 A. 2 d 1 (1941); McNeir v. McNeir, 178 Va. 285, 16 S.E. 2d 632 (1941). 
By way of final conjecture, it appears to this writer that the court will extend this liberality to the recognition of foreign alimony decrees, especially those subject to retroactive modification but which have not been modified.

John B. Dwyer 